\title{
BAYESIAN ESTIMATE OF TELECOMMUNICATION SYSTEMS PREPAREDNESS
}

\author{
V.E. EMELYANOV ${ }^{\mathbf{1}}$, S.P. MATYUK ${ }^{\mathbf{1}}$ \\ ${ }^{1}$ Moscow State Technical University of Civil Aviation, Moscow, Russia
}

\begin{abstract}
The paper assumes a Bayesian estimate of the telecommunication systems availability ratio. Downtime and uptime are described by gamma distributions with positive integer parameters. Estimates of the distribution parameters are obtained using the maximum likelihood method. For the set samples, the values of the desired probability distribution densities are found and an expression for estimating the availability ratio is derived. Numerical estimates for the standard and assumed estimates are given. For a system with two states, a Bayesian estimate of the availability function with consideration of downtime and serviceable condition takes into account the features of backup equipment and the effect of its failure defined by performance reliability and features that ensure the reliability of information signals. The proposed Bayesian approach has the following advantages: it is possible to conduct quantitative estimates with lack of sufficient statistics on functional use indicators; it takes into account all destabilizing factors of various nature; the presence of a lower mean square error compared to traditional methods. To implement the proposed approach that estimates the availability ratio, confidence probabilities are introduced relative to the indicator of failure flows and equipment recovery. The parameters of the a priori information can be determined by different methods or on the basis of sufficient statistical data. To illustrate the discussed calculation algorithm, a digital data transmission system of a standard satellite navigation system consisting of terminal, radio equipment, and a transponder is considered. To estimate the required values, we used data on interruptions in the operation of equipment due to its malfunction during a conditional year. The frequency of downtime caused by signal propagation conditions and equipment failures was evaluated. It was shown that the gamma distribution is suitable for describing the frequency distribution of downtime. The frequency distribution of the cyclicity coefficient with the condition of the selected time interval was also taken into account. Sample mathematical expectations and mean square deviations of the downtime coefficient were found. As a result, the numerical example shows the correctness of using the Bayesian estimate of weighted equipment preparedness.
\end{abstract}

Key words: the availability ratio, gamma distribution, uptime and downtime cycles, estimation of the parameters.

\section{INTRODUCTION}

The technologies used to create modern facilities for radio engineering flights support and aviation telecommunications (REFS and ATC) cause a high level of operational characteristics $[1,2]$. However, the problem with ensuring the reliability of information determined by the operational characteristics using specified equipment is updated. Along with this, there are problems of assessing the availability of equipment arising from the strict requirements of ICAO for the acceptable time of interruptions in work, not to mention the specific requirements for the transfer of confidential information. Any disruption in the operation of REFS and ATC facilities affects the dominant industry indicators, such as flight safety and the throughput of air traffic control zones (ATCZ) [3, 4]. In addition, methods for calculating serviceability characteristics that use the assumption of the exponential law of the uptime function are questionable, since they are based on a priori constancy of the failure rate. In this paper, the authors attempt to assess the availability of equipment and the level of its possible changes $[5,6]$.

\section{RESEARCH METHODS AND METHODOLOGY}

The authenticity of information in telecommunications systems largely depends on the reliability of communication channels. The assumption of an exponential distribution of reliability probability indicators may be unfair if the system operates under changing conditions, which fully applies to telecommunications systems $[7,8]$. Such conditions can be considered as a complex electromagnetic envi- 
ronment, operation during the initial period of operation, the influence of radio wave propagation conditions, etc. In addition, exponential estimates of reliability indicators are inaccurate with limited data $[9,10]$. Also, modern telecommunication systems have a high level of reliability and therefore it is impractical to carry out maintenance with a constant control step along with the use of a priori selected uptime probability distribution functions [11].

In this case, due to the randomness of the parameters caused by the unstable operating environment, we will use the Bayesian approach to evaluate the system availability $[12,13]$.

Let's assume that downtime and uptime times have a gamma distribution with positive integer parameters of the distribution form [14], which allows us to take into account various degradation processes that affect information signals and system redundancy. The Bayesian approach used in this case has the following advantages:

- it is possible to conduct quantitative assessments in the absence of sufficient statistics on failures and recovery;

- consideration of destabilizing factors with various kinds of nature;

- the presence of a lower mean squared error compared to traditional methods $[15,16]$.

To generalize the possibility of extending the proposed model to various telecommunications systems with different communication channels, consider a system that has a "hot" reserve of $\mathrm{N}_{\mathrm{v}}$ functioning and $\mathrm{N}_{\mathrm{u}}$ reserve resources [17, 18].

We define $K_{\Gamma}$ as the availability ratio for the given parameter values, $\widetilde{K}_{\Gamma}$ - availability ratio which takes into account the variation in the availability of resources due to various factors; $\mathrm{n}$ - sampling volume; $\mathrm{T}$ - the cycle period; $\mathrm{T}_{\mathrm{o}}$ - time between failures; $\tau_{\mathrm{B}}$ - time of recovery; $\mathrm{a}, \mathrm{b}-\mathrm{constant}$ parameters of the gamma distribution; $\alpha, \beta$-parameters of the $\mathrm{G}$ - distribution form; $\mathrm{x}_{\mathrm{io}}$ and $\mathrm{y}_{\mathrm{io}}-$ the observed downtime and uptime for $i$-th cycle respectively; $\lambda$ and $\mu-$ the failure and recovery rates.

In accordance with we have [19]:

$$
\widetilde{\mathrm{K}}_{\Gamma}=\sum_{n=0}^{N_{v}}\left(\begin{array}{c}
N_{t} \\
n
\end{array}\right){\frac{n}{N_{a}}}^{k}\left[1-K_{\Gamma}(t)\right]^{N_{t}-n}\left[K_{\Gamma}(t)\right]^{n}+\sum_{n=N_{a}+1}^{N_{t}}\left(\begin{array}{c}
N_{t} \\
n
\end{array}\right){\frac{n}{N_{a}}}^{k}\left[1-K_{\Gamma}(t)\right]^{N_{t}-n}\left[K_{\Gamma}(t)\right]^{n},
$$

where $\mathrm{N}_{\mathrm{t}}=\mathrm{N}_{\mathrm{v}}+\mathrm{N}_{\mathrm{u}}$.

We determine the duration of the cycle $\mathrm{T}$ by adding one functional state and one defective state. For known parameters $\lambda$ and $\mu$ fixed time $t$ :

$$
K_{\Gamma}(t ; \lambda ; \mu)=\frac{\mu}{\lambda+\mu}+\frac{\lambda}{\lambda+\mu} \exp [-(\lambda+\mu) t] .
$$

Estimation of the availability ratio $\widetilde{\mathrm{K}}_{\Gamma}(t ; \lambda ; \mu)$ it is obtained by substituting estimates $\lambda$ and $\mu$ by maximum likelihood method $(\hat{\lambda}$ and $\widehat{\mu})$ into expression (2). The corresponding likelihood functions are maximized and as a result we have:

$$
\hat{\lambda}=\frac{n}{\sum_{i=1}^{n} x_{i}} ; \hat{\mu}=\frac{n}{\sum_{i=1}^{n} y_{i}} ;
$$

To implement the Bayesian approach, we introduce confidential probabilities on $\lambda$ and $\mu$ as statically independent and having gamma distributions:

$$
\begin{aligned}
& F_{\lambda}(\lambda ; \alpha ; a)=F(a \lambda ; \alpha), \\
& F_{\mu}(\mu ; \beta ; b)=F(b \mu ; \beta) .
\end{aligned}
$$


In relations (3) and (4) $F_{\lambda}(\lambda ; \alpha ; a)=F(a \lambda ; \alpha)-$ a priori distributions of the degree of confidence on $\lambda$ and $\mu$, respectively. They are more diverse in shape and content, and, more importantly, they are consistent with exponential ones. Parameters of a priori information can be determined in various ways.

Assume that for $\mathrm{T}_{\mathrm{o}}$ and $\tau_{\mathrm{B}}$ there is a sampling $\left(\mathrm{x}_{\mathrm{i}}, \mathrm{y}_{\mathrm{i}}\right), i=\overline{1, n}$. The posterior probability distribution density (PDD) $\lambda, f_{\lambda}\left(\lambda \mid x_{1}, x_{2}, \ldots, x_{n}\right)$ has the form

$$
f_{\lambda}\left(\lambda \mid x_{1}, x_{2}, \ldots, x_{n}\right)=\frac{f_{\lambda}(\lambda) \times \mathrm{L}\left(x_{1}, x_{2}, \ldots, x_{n} ; \lambda\right)}{\int_{0}^{\infty} f_{\lambda}(\hat{\lambda}) \times \mathrm{L}\left(x_{1}, x_{2}, \ldots, x_{n} ; \lambda\right) \mathrm{d} \hat{\lambda}}=\frac{\hat{\lambda}^{\alpha+\mathrm{n}-1} \exp \left[-\lambda\left(\mathrm{a}+\sum_{i=1}^{n} x_{i}\right)\right]}{\int_{0}^{\infty} \hat{\lambda}^{\alpha+\mathrm{n}-1} \exp \left[-\hat{\lambda}\left(\mathrm{a}+\sum_{i=1}^{n} x_{i}\right)\right] d \hat{\lambda}^{\prime}}
$$

Where

$$
L\left(x_{1}, x_{2}, \ldots, x_{n} ; \lambda\right)=\hat{\lambda} \exp \left[-\hat{\lambda} \sum_{i=1}^{n} x_{i}\right]
$$

Because,

$$
\mathrm{f}(\lambda)=\frac{a}{(a-1) !} a \lambda^{n-1 \lambda}+\lambda \exp \left[-\lambda\left(a+\sum_{i=1}^{n} x_{i}\right)\right]
$$

expression (6) can be written as:

$$
f_{\lambda}\left(\lambda \mid x_{1}, x_{2}, \ldots, x_{n}\right)=\frac{a+\sum_{i=1}^{n} x_{i}}{\Gamma(\alpha+n)}\left[\lambda\left(a+\sum_{i=1}^{n} x_{i}\right)\right]^{\alpha+\mathrm{n}-1} \exp \left[-\lambda\left(a+\sum_{i=1}^{n} x_{i}\right)\right] .
$$

Expression (8) is a gamma distribution with parameters

$$
\begin{gathered}
\left\{\lambda\left(a+\sum_{i=1}^{n} x_{i}\right)\right\} \text { and }(\alpha+\mathrm{n}), \text { i.e., } \\
\Gamma_{\lambda}\left(\lambda \mid x_{1}, x_{2}, \ldots, x_{n}\right)=\Gamma_{\lambda}\left[\lambda\left(a+\sum_{i=1}^{n} x_{i}\right) ;(\alpha+\mathrm{n})\right] .
\end{gathered}
$$

Similar ratio can be obtained for $\mu$ :

$$
\Gamma\left(\mu \mid y_{1}, y_{2}, \ldots, y_{n}\right)=\Gamma\left[\mu\left(b+\sum_{i=1}^{n} y_{i}\right) ;(\beta+\mathrm{n})\right]
$$

\section{RESEARCH RESULTS}

Assuming that the loss function is a square function, the Bayesian estimate $K_{\Gamma}(t ; \lambda ; \mu)$ it is a function that minimizes losses in relation to a posteriori model, and in case of static data - the a prior model $\lambda$ and $\mu$, i.e.

$$
\lambda_{i}(t ; \alpha ; \beta ; a ; b)=\iint_{0}^{\infty} K_{\Gamma}(t ; \lambda ; \mu) f_{\mathrm{i}}\left(\lambda \mid x_{1}, x_{2}, \ldots, x_{n}\right) f_{\mathrm{i}}\left(\mu \mid x_{1}, x_{2}, \ldots, x_{n}\right) d \lambda d \mu,
$$

if there is a sampling $\left(\mathrm{x}_{\mathrm{i}}, \mathrm{y}_{\mathrm{i}}\right), i=\overline{1, n}$. sessment:

Substituting (9) and (10) in the ratio (11), we get the following formula for preparedness as-

$$
\begin{aligned}
& \lambda_{i}(t ; \alpha ; \beta ; a ; b)=\frac{\left(a+\sum_{i=1}^{n} x_{i}\right)\left(b+\sum_{i=1}^{n} y_{i}\right)}{(\alpha+\mathrm{n}-1)(\beta+\mathrm{n}-1)}+ \\
& +\int_{0}^{t}\left[\begin{array}{c}
\left\{\int_{0}^{\infty} \lambda\left(a+\sum_{i=1}^{n} x_{i}\right)^{\alpha+\mathrm{n}-1} \exp \left[-\lambda\left(a+\sum_{i=1}^{n} x_{i}\right)\right] d \lambda\right\} \\
\left\{\int_{0}^{\infty} \mu\left(b+\sum_{i=1}^{n} y_{i}\right)^{\beta+\mathrm{n}-1} \exp \left[-\mu\left(b+\sum_{i=1}^{n} y_{i}\right)\right] \exp [-\mu(1-s)] d \mu\right\}
\end{array}\right] d s
\end{aligned}
$$




\section{DISCUSSION OF THE OBTAINED RESULTS}

The above results were used for numerical calculation of the radio link availability ratio for broadcasting information from the satellite navigation and communication system. The statistical data presented in were taken as a basis [20]. The system belongs to the class of $1 \times 2\left(\mathrm{~N}_{\mathrm{v}}=2, \mathrm{~N}_{\mathrm{u}}=1\right)$.

Without stopping at intermediate calculations, we present the standard value of $r$ and the value obtained using Bayesian estimation. They are 0.99996 and 0.9954 , respectively.

The proposed algorithm can be useful if it is necessary to obtain the parameters of interest used when choosing a strategy for technical operation of telecommunications systems and (or) their functional elements.

\section{CONCLUSION}

These results differ from the values of the investigated parameters using standard calculation methods. It should be noted that at various stages of the process of technical operation of equipment in accordance with [7], it is possible to use other distribution laws, which in turn is a further direction of the authors' research. Along with this, it should be noted that the development of this method, in our view, will allow us to assess the risks that arise when the reliability of information processing is unstable.

\section{REFERENCES}

1. Gorbunov, Yu.N. (2019). Improving the accuracy of measurement time intervals of radio reception in the framework of recursive multi-stage Bayesian estimates. RENSIT, vol. 11, no. 3, pp. 291-298. DOI: 10.17725/rensit.2019.11.291 (in Russian)

2. Bakulin, M.G., Kreyndelin, V.B., Grigoriev, V.A., Aksenov, V.O. and Schesnyak, A.S. (2020). Bayesian estimation with successive rejection and utilization of a priori knowledge. Radiotehnika i Elektronika, vol. 65, no. 3, pp. 257-266. DOI: 10.31857/S0033849420030031 (in Russian)

3. Barlow, R.E. and Proschan, F. (1984). Statisticheskaya teoriya nadezhnosti $i$ ispytaniya na bezotkaznost [Statistical theory of reliability and life testing: probability models]. Translated from English by I.A. Ushakov. Moscow: Nauka, 328 p. (in Russian)

4. Barzilovich, E.Yu., Emelyanov, V.E., Smirnov, V.V. and Topchnev, V.P. (2000). Nekotoryye optimalnyye algoritmy upravleniya $v$ sistemakh razlichnoy prirody [Some optimal control algorithms in systems of different nature]. Nauchnyy Vestnik MGTU GA, no. 32, pp. 5-16. (in Russian)

5. Biryukov, I.D., Buchuchan, P.V. and Timoshenko, P.I. (2020). Information processing algorithms in aviation-based radioelectronic surveillance systems. RENSIT, vol. 12, no. 4, pp. 517-528. DOI: 10.17725/rensit.2020.12.517 (in Russian)

6. Gorshenin, A.K. (2018). Data noising by finite normal and gamma mixtures with application to the problem of rounded observations. Informatics and Applications, vol. 12, no. 3, pp. 28-34. DOI: $10.14357 / 19922264180304$ (in Russian)

7. Emelyanov, V.E. and Logvin, A.N. (2014). Tekhnicheskaya ekspluatatsiya aviatsionnogo radioelektronnogo oborudovaniya [Technical use of aviation radio-electronic equipment]. Moscow: MORKNIGA, 730 p. (in Russian)

8. Korolev, V.Y., Korchagin, A.Y. and Zeifman, A.I. (2015). On the convergence of distributions of statistics constructed from samples of random size to a multivariate generalized variancegamma distributions. Doklady Mathematics, vol. 91, no. 3, pp. 332-335. DOI: $10.1134 / \mathrm{S} 1064562415030205$

9. Kochkarov, A.A., Razin'kov, S.N., Timoshenko, A.V. and Shevtsov, V.A. (2020). Comprehensive method of information resources control ensuring the security of telecommunication sys- 
tems of aviation monitoring complexes. Izvestiya vysshikh uchebnykh zavedenii. Aviatsionnaya tekhnika, pp. 158-166. (in Russian)

10. Kudryavtsev, A.A., Palionnaia, S.I. and Shorgin, V.S. (2018). A priori inverse gamma distribution in Bayesian queuing models. Systems and Means of Informatics, vol. 28, no. 4, pp. 54-60. DOI: 10.14357/08696527180406 (in Russian)

11. Litvinenko, R.S., Jamshhikov, A.S. and Bagaev, A.V. (2016). The practice of applying gamma distribution the theory of reliability of technical systems. Tekhnicheskiye nauki - ot teorii $\mathrm{k}$ praktike, no. 56, pp. 153-159. (in Russian)

12. Mazalov, V.V. and Nikitina, N.N. (2018). The maximum likelihood method for detecting communities in communication networks. Vestnik of Saint Petersburg University. Applied Mathematics. Computer Science. Control Processes, vol. 14, no. 3, pp. 200-214. DOI: 10.21638/11702/spbu10.2018.302 (in Russian)

13. Sidorov, I.G. (2018). Linear minimax filtering of a stationary random process under the condition of the interval fuzziness in the state matrix of the system with a restricted variance. Journal of Communications Technology and Electronics, vol. 63, no. 8, pp. 902-907. DOI: 10.1134/S003384941807015X (in Russian)

14. Alquier, P. and Guedj, B. (2017). An oracle inequality for quasi-Bayesian nonnegative matrix factorization. Mathematical Methods of Statistics, no. 26, pp. 55-67. DOI: $10.3103 / \mathrm{S} 1066530717010045$

15. Cuo, W. (1986). Bayes weighted availability for a digital radio transmission system. IEEE. Transactions of Reliability, vol. R-35, pp. 201-207.

16. Hadj-Amar, B., Finkenstädt, R.B., Fiecas, M., Lévi, F. and Huckstepp, R. (2020). Bayesian model search for nonstationary periodic time series. Journal of the American Statistical Association, vol. 115, issue 531, pp. 1320-1335. DOI: 10.1080/01621459.2019.1623043

17. Hamura, Y. and Kubokawa, T. (2019). Bayesian predictive distribution for a negative binomial model. Mathematical Methods of Statistics, vol. 28, pp. 1-17. DOI: $10.3103 / \mathrm{S} 1066530719010010$

18. Al-Labadi, L. and Zarepour, M. (2017). Two-sample Kolmogorov-Smirnov test using a Bayesian nonparametric approach. Mathematical Methods of Statistics, vol. 26, pp. 212-225. DOI: $10.3103 / \mathrm{S} 1066530717030048$

19. Priem, R., Bartoli, N., Diouane, Y. and Sgueglia, A. (2020). Upper trust bound feasibility criterion for mixed constrained Bayesian optimization with application to aircraft design. Aerospace Science and Technology, vol. 105, ID 105980. DOI: 10.1016/j.ast.2020.105980

20. Wang John, C.H., Shi Kun Tan, Kin Huat Low (2020). Three-dimensional (3D) MonteCarlo modeling for UAS collision risk management in restricted airport airspace. Aerospace Science and Technology, vol. 105, ID 105964. DOI: 10.1016/j.ast.2020.105964

\section{INFORMATION ABOUT THE AUTHORS}

Vladimir E. Emelyanov, Doctor of Technical Sciences, Associate Professor, Professor of the Radio Engineering and Information Security Chair, Moscow State Technical University of Civil Aviation,v.emelianov@mstuca.aero.

Sergei P. Matyuk, Candidate of Technical Sciences, Associate Professor of the Radio Engineering and Information Security Chair, Moscow State Technical University of Civil Aviation, s.matiuk@mstuca.aero. 


\title{
БАЙЕСОВСКАЯ ОЦЕНКА ГОТОВНОСТИ СИСТЕМ ТЕЛЕКОММУНИКАЦИИ
}

\author{
В.Е. Емельянов ${ }^{1}$, С.П. Матыюк \\ ${ }^{1}$ Московский государственный технический университет гражданской авиации, \\ 2. Москва, Россия
}

В работе предполагается байесовская оценка коэффициента готовности телекоммуникационных систем. Времена простоя и исправного состояния описываются гамма-распределениями с целыми положительными параметрами. С помощью метода максимального правдоподобия получены оценки параметров распределения. Для установленных выборок найдены значения искомых плотностей распределения вероятностей и выведено выражение для оценки коэффициента готовности. Приведены численные оценки для стандартной и предполагаемой оценок.Для системы имеющей два состояния, байесовская оценка функции готовности с учетом времени простоя и исправного состояния позволяет учесть, как особенности резервирования оборудования, так и эффект его отказов определяемых характеристиками безотказности и особенностями обеспечения достоверности информационных сигналов. Предлагаемый байесовский подход имеет следующие преимущества: возможное проведение количественных оценок при отсутствии достаточной статистики о показателях функционального использования; учет всех дестабилизирующих эффектов различной природы; наличиеменышей средней квадратичной ошибки по сравнению с традиционными методами. Для реализации предложенного подхода оценки коэффициента готовности введены доверительные вероятностиотносительнопоказателя потоков отказов и восстановления оборудования. Параметры априорной информации могут определяться различными методами, или на основании достаточных статистических данных. Для иллюстрации рассмотренного алгоритма расчета рассмотрена цифровая система трансляции данных стандартной спутниковой навигационной системы состоящей из оконечного оборудования, радиооборудования, ретранслятора. Для оценок искомых величин использовались данные по перерывах в работе оборудования из-за его неисправности в течение условного года. Оценивались частота простоев, вызванная условиями распространения сигналов и отказами оборудования. Было показано, что для описания частотного распределения длительности простоя подходит гамма-распределение. Также учитывались частотное распределение коэффициента цикличности с условием выбранного интервала времени. Были найдены выборочные математические ожидания и средние квадратичные отклонения коэффициента простоя. В результате, численный пример показывает корректность использования байесовской оценки взвешенной готовности оборудования.

Ключевые слова: коэффициент готовности, гамма-распределение, циклы функционирования и простоя, оценка параметров.

\section{СПИСОК ЛИТЕРАТУРЫ}

1. Горбунов Ю.Н. Повышение точности измерения временных интервалов радиоприема в рамках рекурсивных многоэтапных Байесовских оценок // РЭНСИТ. 2019. Т. 11, № 3. C. 291-298. DOI: 10.17725/rensit.2019.11.291

2. Бакулин М.Г. Байесовское оценивание с последовательным отказом и учетом априорных знаний / М.Г. Бакулин, В.Б. Крейнделин, В.А. Григорьев, В.О. Аксенов, А.С. Щесняк // Радиотехника и электроника. 2020. T. 65, № 3. C. 257-266. DOI: 10.31857/S0033849420030031

3. Барлоу Р., Прошан Ф. Статистическая теория надежности и испытания на безотказность / Пер. с англ. И.А. Ушакова. М.: Наука, 1984. 328 с.

4. Барзилович Е.Ю. Некоторые оптимальные алгоритмы управления в системах различной природы / Е.Ю. Барзилович, В.Е. Емельянов, В.В. Смирнов, В.П. Топчнев // Научный Вестник МГТУ ГА. 2000. № 32. С. 5-16.

5. Бирюков И.Д., Бучучан П.В., Тимошенко П.И. Алгоритмы обработки информации в авиационных системах радиоэлектронного наблюдения // РЭНСИТ. 2020. Т. 12, № 4. C. 517-528. DOI: 10.17725/rensit.2020.12.517

6. Горшенин А.К. Зашумление данных конечными смесями нормальных и гаммараспределений с применением к задаче округления наблюдений // Информатика и ее применения. 2018. Т. 12, № 3. С. 28-34. DOI: 10.14357/19922264180304

7. Емельянов В.Е., Логвин А.Н. Техническая эксплуатация авиационного радиоэлектронного оборудования. М.: МОРКНИГА, 2014. 730 с.

8. Королев В.Ю., Корчагин А.Ю., Зейфман А.И. О сходимости распределений статистик, построенных по выборкам случайного объема, к многомерным обобщенным дисперси- 
онным гамма-распределениям // Доклады Академии наук. 2015. Т. 462, № 4. С. 394. DOI: $10.7868 / \mathrm{S} 0869565215160045$

9. Кочкаров А.А. Комплексный метод управления информационными ресурсами при обеспечении безопасности телекоммуникационных систем авиационных комплексов мониторинга / А.А. Кочкаров, С.Н. Разиньков, А.В. Тимошенко, В.А. Шевцов // Известия высших учебных заведений. Авиационная техника. 2020. № 2. С. 158-166.

10. Кудрявцев А.А., Палионная С.И., Шоргин В.С. Априорное обратное гаммараспределение в байесовских моделях массового обслуживания // Системы и средства информатики. 2018. Т. 28, № 4. С. 54-60. DOI: 10.14357/08696527180406

11. Литвиненко Р.С., Ямщиков А.С., Багаев А.В. Практика применения гаммараспределения в теории надежности технических систем // Технические науки - от теории к практике. 2016. № 56. С. 153-159.

12. Мазалов В.В., Никитина Н.Н. Метод максимального правдоподобия для выделения сообществ в коммуникационных сетях // Вестник Санкт-Петербургского университета. Прикладная математика. Информатика. Процессы управления. 2018. Т. 14, № 3. С. 200-214. DOI: $10.21638 / 11702 /$ spbu10.2018.302

13. Сидоров И.Г. Минимаксная линейная фильтрация стационарного случайного процесса в условиях интервальной нечеткости матрицы состояния системы с ограниченной дисперсией // Радиотехника и электроника. 2018. Т. 63, № $8 . \quad$ С. 831-836. DOI: $10.1134 / \mathrm{S} 003384941807015 \mathrm{X}$

14. Alquier P., Guedj B. An oracle inequality for quasi-Bayesian nonnegative matrix factorization // Mathematical Methods of Statistics. 2017. № 26. Pp. 55-67. DOI: $10.3103 / \mathrm{S} 1066530717010045$

15. Cuo W. Bayes weighted availability for a digital radio transmission system // IEEE. Transactions of Reliability, 1986. Vol. R-35. Pp. 201-207.

16. Hadj-Amar B. Bayesian model search for nonstationary periodic time series / B. HadjAmar, R.B. Finkenstädt, M. Fiecas, F. Lévi, R. Huckstepp // Journal of the American Statistical Association. 2020. Vol. 115, iss. 531. Pp. 1320-1335. DOI: 10.1080/01621459.2019.1623043

17. Hamura Y., Kubokawa T. Bayesian predictive distribution for a negative binomial model // Mathematical Methods of Statistics. 2019. Vol. 28. Pp. 1-17. DOI: 10.3103/S1066530719010010

18. Al-Labadi L., Zarepour M. Two-sample Kolmogorov-Smirnov test using a Bayesian nonparametric approach // Mathematical Methods of Statistics. 2017. Vol. 26. Pp. 212-225. DOI: $10.3103 / \mathrm{S} 1066530717030048$

19. Priem R. Upper trust bound feasibility criterion for mixed constrained Bayesian optimization with application to aircraft design / R. Priem, N. Bartoli, Y. Diouane, A. Sgueglia // Aerospace Science and Technology. 2020. Vol. 105. ID 105980. DOI: 10.1016/j.ast.2020.105980

20. Wang John C.H., Shi Kun Tan, Kin Huat Low. Three-dimensional (3D) Monte-Carlo modeling for UAS collision risk management in restricted airport airspace // Aerospace Science and Technology. 2020. Vol. 105. ID 105964. DOI: 10.1016/j.ast.2020.105964

\section{СВЕДЕНИЯ ОБ АВТОРАХ}

Емельянов Владимир Евгеньевич, доктор технических наук, доцент, профессор кафедры основ радиотехники и защиты информации МГТУ ГА, v.emelianov@mstuca.aero.

Матыюк Сергей Петрович, кандидат технических наук, доцент кафедры основ радиотехники и защиты информации МГТУ ГА, s.matiuk@mstuca.aero.

$\begin{array}{llll}\text { Поступила в редакцию } & 01.12 .2020 & \text { Received } & 01.12 .2020 \\ \text { Принята в печать } & 28.01 .2021 & \text { Accepted for publication } & 28.01 .2021\end{array}$

